\title{
"My garden is a great help": gender and urban gardening in Buea, Cameroon
}

\author{
Ivo Ngome • Dick Foeken
}

Published online: 23 October 2010

(C) The Author(s) 2010. This article is published with open access at Springerlink.com

\begin{abstract}
At a time of economic crisis and sharply rising food prices, urban farming is increasingly helping to sustain households. Gender is generally thought to be a key variable in this but studies are still in their infancy. Looking at the phenomenon from a livelihood perspective and based on a survey carried out in Buea, Cameroon, this paper deals with a number of key issues related to gender and urban gardening, including access to resources, division of labour and the benefits and challenges encountered. An additional variable, namely the marital status of the gardener, is also considered. There appear to be important differences between male and female gardeners in various respects, and marital status plays a role not only among female gardeners but to some extent among male gardeners too.
\end{abstract}

Keywords Urban gardening - Gender - Marital status $\cdot$ Buea $\cdot$ Cameroon

\section{Introduction}

The food and agricultural sector forms the backbone of most African economies, offering a livelihood for

\section{Ngome}

Department of Geography, University of Buea,

Buea, Cameroon

e-mail: ngomeiswell@yahoo.com

D. Foeken $(\square)$

African Studies Centre, Leiden, The Netherlands

e-mail: dfoeken@ascleiden.nl a large proportion of Africa's population. However, the sector has been in decline in many countries since the 1960s and African cities are now suffering from food insecurity. Urban areas have been particularly hard hit by declining economies and the structural adjustment policies introduced during the 1980 and 1990s, the costs of which were disproportionately felt by the urban poor (Rakodi 2002b). Life in urban areas has become more expensive while employment in the formal sector has decreased and real wages have not kept pace with price increases, or have even declined in absolute terms (Tacoli 2002; Bah et al. 2003; Beauchemin and Bocquier 2003). More recently, the prices of food and other basic commodities have been increasing due to the global economic crisis. In West Africa alone, there have been reports of serious social unrest in response to the soaring costs of food in at least five different countries (Cameroon, Burkina Faso, Côte d'Ivoire, Senegal and Mauritania).

People have responded to this decline in purchasing power in a number of ways, notably by diversifying their incomes (e.g. Ellis 2000; De Haan and Zoomers 2003; Kaag et al. 2004). A wide range of activities in the informal sector are being undertaken (e.g. Hansen and Vaa 2004) and among these, urban agriculture is an important one. Although urban farming is often seen as a survival strategy of the urban poor, it is practised by urban residents in all income categories. There are even towns where the poor are underrepresented among urban farmers (Foeken and Owuor 2008), but for poor and rich 
urban farmers alike, urban farming is a way "to subsidise my income" (Foeken 2006).

Not surprisingly therefore, urban farming is usually looked at from the perspective of the (urban) livelihoods approach. ${ }^{1}$ Urban residents are not seen as passive victims of adverse circumstances but as actors developing actions and strategies-in this case urban farming-aimed at preserving a certain livelihood level. The key word is access, with the crucial question being to what extent people have access to natural, human, physical, financial and social resources (or assets or capitals). ${ }^{2}$ According to Bebbington (1999: 2022), access is so important that "[it is] perhaps the most critical resource of all".

Much has been written about livelihoods, resources and access, but in the context of this paper one observation-besides the above-mentioned diversification of income sources-is of particular importance, namely that the choice of activities and strategies depends on a number of household and individual characteristics, a very important one being gender (Beall 2002). In general, urban employment opportunities for women in industry, trade and commerce are smaller than for men (Momsen 2004). Thus, according to Kanji (1995), women increase their informal income-generating activities to cope with the declining purchasing power of their household income by engaging in activities that are generally concentrated in or near their urban homes (see e.g. Wallman 1996; Whitehead 2002; Owuor and Foeken 2006). This is related to the fact that women's time-and that of women in low(er) income households in particular-is to a large extent spent on such activities as cooking, housekeeping and child rearing (see e.g. Levine et al. 2001). For that reason, urban farming is an attractive informal livelihood option for these women because "it can be done close to the home, little cash is needed,

\footnotetext{
${ }^{1}$ For the livelihood approach, see e.g. Chambers (1983), Jones (1999), Rakodi (2002a), De Haan and Zoomers (2003), and Kaag et al. (2004). Besides the livelihood perspective, one can look at urban farming from other perspectives as well, such as poverty alleviation, improving a town's food security, providing food and income for lower-income groups, productively using currently unused land, 'greening' the urban landscape, and strengthening social relationships (community farming).

${ }^{2}$ For more details about these resources in an (African) urban setting, see Rakodi (2002a) and Brown and Lloyd-Jones (2002). For a case study on urban farming from a livelihood perspective, see for instance Foeken (2006) and Owuor and Foeken (2006).
}

and it combines well with the prime responsibilities of women" (Wilbers et al. 2004b: 2). A related conclusion was drawn by Gockowski et al. (2003: 234) who noticed that among the reasons for the high level of participation in the cultivation and marketing of traditional leafy vegetables in Yaounde, Cameroon, "are the low capital requirements for entry, which allows even the poorest households to participate".

Focusing on urban crop cultivation (or gardening) and using a case study from the town of Buea in Cameroon, this paper deals with a number of gender issues in urban farming. The central question is to what extent female gardeners were disadvantaged compared to male gardeners. Few studies have focused on this question, but from what has been published so far, the impression is left that women are indeed disadvantaged in terms of access to resources (Hovorka et al. 2009), and this applies to unmarried women (female-headed households) in particular (see e.g. Foeken 2006).

Gender and urban agriculture

To fully understand the importance of urban farming for a household's livelihood, it is essential to look at the different gender-specific roles of its members. ${ }^{3}$ Hovorka et al. (2009: 13-25) distinguish six "key gender issues in urban agriculture": (1) women's involvement, (2) benefits and challenges, (3) division of labour, (4) knowledge and preferences, (5) access to land and control over resources, and (6) decisionmaking. These six 'key issues' are briefly discussed here.

It is generally held that women predominate in urban agriculture because they bear responsibility for household sustenance. They also tend to have lower educational levels than men and therefore have more difficulty finding formal employment (Hovorka 2001). However, levels of female participation in urban farming vary across Sub-Saharan Africa. Women generally dominate farming in eastern and southern Africa, although for instance in the small town of Rhini, in the Eastern Cape province of South Africa, "female and male practitioners who cultivate a garden (...) were evenly distributed" (Thornton 2008: 255). In West Africa, men tend to have a leading role, as the

\footnotetext{
${ }^{3}$ For good, recent overviews, see Wilbers et al. (2004a) and Hovorka et al. (2009).
} 
case studies in Wilbers et al. (2004a)and Hovorka et al. (2009) illustrate. Parrot et al. (2008: 250) noticed an important change between 1995 and 2004 among periurban farmers in Muea (Southwest Cameroon): whereas in 1995, "the typical farmer in horticulture (...) was a woman, (...) sometimes the head of the household", in 2004 "more men, head of the household, adopted horticulture". The involvement of men and women in urban farming can also depend on the production system. For instance, traditional vegetable farming in West Africa is dominated by women and they also play an important role in marketing their produce (Kessler et al. 2004; Danso et al. 2004; Hope et al. 2009). In East Africa, women also dominate vegetable gardening, while men are more active in keeping large livestock (e.g. Kiguli and Kiguli 2004; Foeken 2006).

Urban farming among men tends to be an incomegenerating activity but for women-and especially for those lacking access to formal employment-it is a viable alternative to wage labour that offers both food and an income (Gbadegesin 1991; Nabulo et al. 2004). Several studies have shown that women generally face more challenges than men, notably regarding access to land and productive resources (Wilbers et.al. 2004b; Kessler et al. 2004; Anosike and Fasona 2004; Foeken 2006).

In addition to the overall division of tasks within urban households, which tend to be culturally determined, labour in urban agriculture is often genderspecific too. The tasks men and women perform vary according to factors such as their cultural background, the socio-economic status of the household and the types of crops or livestock involved (Hovorka et al. 2009: 17). In general, farm work in East and Southern Africa is mostly done by women (Toriro 2009; Ishani 2009), whereas these tasks in West Africa are shared more equally (see Hope et al. 2009).

Knowledge of farming-related practices differs with educational level (which, as said, is generally lower among women), the type of farming (women generally know more about crops, men more about livestock), and farming technologies (men know more about technically advanced practices and chemical inputs) (Hovorka et al. 2009). In terms of improving knowledge by means of extension services and technical support, women are frequently disadvantaged because of the more traditional types of farming they engage in (Kessler et al. 2004; Toriro
2009). There are normally gender differences regarding certain preferences and priorities, such as roles and responsibilities, the location of plots, modes of production and the use of benefits (Hovorka et al. 2009).

Practically all the studies considering gender aspects related to urban agriculture stress the disadvantaged position of women regarding access to land (see Wilbers et al. 2004a; Hovorka et al. 2009). In many cases, women may have access to land but it is the men who own it (Ishani 2009); in Kevane's (2004: 48) words, "women are owners of crops and not owners of fields". As a result, women often have to rely on plots that are smaller, more peripheral and/or of lower quality (Kessler et al. 2004; Anosike and Fasona 2004; Nabulo et al. 2004), although there are also examples of equal access to land among men and women (Hope et al. 2009; Toriro 2009; Njenga et al. 2009). Women generally face more constraints regarding other productive inputs, especially the more expensive ones like irrigation and chemicals (Foeken 2006; Wilbers et al. 2004b; Chancellor 2004; Toriro 2009). The same goes for access to microcredit (Nabulo et al. 2004; Toriro 2009). As a result of the above-mentioned constraints, productivity and harvests among female farmers are usually (much) smaller than among male farmers (e.g. Foeken 2006: 61).

There is a relationship between access to land and inputs, on the one hand, and the power to make decisions, on the other, at least in male-headed households with one or more female spouses (Hovorka et al. 2009). The few studies paying attention to this gender aspect report that women have a bigger say in traditional (vegetable) farming, while men are more likely to decide on financial investments and sales and the use of any income generated (Toriro 2009).

In sum, "the patterns of key gender issues that emerge from the [literature] are overwhelmingly similar, revealing that in most urban agriculture contexts men own land, have access to greater resources, make decisions, and reap more benefits than women" (Hovorka et al. 2009: 14). It should be mentioned, however, that there are also studies in which less clear-cut gender differences were recorded, such as the citywide surveys in Mbeya and Morogoro in Tanzania (Foeken et al. 2004) and a study among vegetable farmers in Accra (Hope et al. 2009). 
The Buea study

Given the vastness of the above 'key gender issues' and the available funding, the present study focused on a limited number of gender issues in urban farming, such as the reasons for urban farming, access to land, crop choice, access to certain inputs, the division of labour, and the benefits of urban farming as well as the challenges. The study was carried out in three adjoining neighbourhoods called Upper Farms, Middle Farms and Lower Farms in the urban agglomeration of Buea in south-western Cameroon. ${ }^{4}$ Buea is situated on the eastern slopes of Mt Cameroon and enjoys fertile volcanic soils and plenty of rainfall. Farming within the town's boundaries has been common practice since the start of the colonial period, not only among Europeans but also among Africans (Page 2002). A study carried out by Ngwa (1987) in the mid-1980s revealed that most urban farmers were government employees who were growing crops primarily for the pleasure they received from doing so and, to a lesser extent, for financial gain. Ten years later, the proportion of households involved in agriculture appeared to have increased considerably ${ }^{5}$ and plots had become bigger, while the main reason for practising farming was now financial due to the severe salary cuts and retrenchments in the context of Cameroon's structural adjustment policies (Page 2002).

Buea is growing rapidly, which is being fuelled by the annual immigration of some 7,000 persons to the country's only English-language university (Folifac et al. 2009). The population of the town proper is about 57,000 but the agglomeration pushes this figure up to about 250,000 inhabitants (Ibid.). Buea is a typical administrative town with "a particularly high proportion of civil servants" (Page 2002: 46). The rapid rate of urbanization has meant that there is a huge demand for food which has pushed up the prices of foodstuffs. ${ }^{6}$ Buea has virtually no secondary

\footnotetext{
${ }^{4}$ Middle Farms and Lower Farms have recently been grouped together into one area called Lower Farms. What is described here is the situation as it was at the time of the survey, i.e. three different areas.

5 To the extent that civil servants talked of themselves in such terms as "we're all farmers now" (Page 2002: 48).

${ }^{6}$ For instance, the price of a small basket of tomatoes in Great Soppo market rose from CFA 250 to CFA 650 between 1999 and April 2008 and the price of a single cabbage in Muea
}

(industrial) economic activity that could offer jobs to the unemployed and even the few who are fortunate enough to have employment, such as hairdressers, police officers, school teachers, university lecturers, business persons or penitentiary officers, complain about the difficulties they face in feeding their households. Many people have thus resorted to urban farming to complement the family's food supply and improve their household's income.

Unlike other towns in the South West Region of Cameroon where animal husbandry and large-scale farming of food crops such as plantains and cassava are common, in Buea farmers concentrate on urban gardening, i.e. the cultivation of crops for food and/or income purposes. For example, there is no poultry in Buea, while no one is known for rearing goats/sheep for the market, or keeping bees or fish. The town is supplied with such products from other towns, but fresh vegetables are produced locally as people take advantage of the enabling weather, fertile volcanic soils and the fact that it does not require much land to raise a garden.

The town of Buea is very hilly, which generally makes agriculture challenging, but Upper Farms, Middle Farms and Lower Farms happen to be located on relatively level terrain that is suitable for gardening. ${ }^{7}$ This may also explain why most government offices and government-owned open spaces, which are now rented out to gardeners, are found in this area of town. In addition, the three areas are located near deep ravines, some of which retain water even in the dry season when gardening is at its peak. The three neighbourhoods enjoy good road networks and are strategically located near Great Soppo and Muea markets to allow for the easy transportation of vegetables to sell. However, the major problem is that these positive externalities have made the area very attractive for other urban land uses as well, such as real estate development, which casts doubts about how long urban gardening will survive here.

In terms of socio-economic status, there is some difference between Upper Farms and Middle Farms on the one hand, and Lower Farms on the other.

\footnotetext{
Footnote 6 continued market from CFA 100 to CFA 500 (price observations made in April 2008 by first author).

7 The name 'Farms' refers to the food production that was common in these areas during the colonial period (Page 2002).
} 
Upper and Middle Farms are built around Buea's two main prisons and many of the residents are employed in the public service as penitentiary officers. Most of the houses there are government-owned and rented by the residents. Lower Farms has fewer governmentowned houses and public offices and fewer residents employed in the public service. Hence, residents have more varied occupations, if they are in employment at all. Upper and Middle Farms can be described as medium-income areas and Lower Farms as a low-tomedium-income area.

Fieldwork for the study was done between June 2006 and December 2007. The main part consisted of a survey using a structured questionnaire among 100 male gardeners and 100 female gardeners. In addition, field observations on gardening practices were recorded. Secondary data were obtained from the University of Buea Library, the National Geographic Centre in Yaoundé, private libraries, as well as local administrative offices.

The 200 gardeners were selected by means of the snowball circulation technique, in which additional participants are added via referrals from initial participants. Given the limited financial funding for this study, this sampling method was considered to be suitable to find out quickly who was in charge of which plot, i.e. to identify the right person to interview. During sampling, it was seen to it that male and female gardeners were never from the same household. Moreover, male gardeners were only selected if they were also the head of their household. ${ }^{8}$ Only one person was thus interviewed from each household, namely the person who (according to him/herself) was

\footnotetext{
$\overline{8}$ The rationale behind this was as follows. In the research area it is common to find several adult men living in one house, with just one woman cooking for all of them. It is also not rare to find a man and his wife (and their children in some cases) living permanently as members of a household in which neither of them is the household head. The real household head may also have a wife and children but they are accommodating another family (like a household within a household). Including such men in the sample runs the risk of getting wrong answers or "don't knows" on questions regarding household characteristics as well as on questions who rented the land, who decides what is planted, who buys the seeds and farm chemicals, who decides what is sold from the crops, who performs which labour, who participates in seminars and workshops about the garden, etc. To avoid such confusion, it was decided to deal only with the 'ultimate head-of-household' for men as well as the 'ultimate woman-in-the-house' for women.
}

effectively in charge of the household's garden. Out of the 200 questionnaires, 95 were administered in Middle Farms, 60 in Upper Farms, 40 in Lower Farms and another 5 in neighbouring Bonduma where urban gardening is also practised.

Out of the 100 female gardeners, 39 were the head of their household, which made a comparison possible between male-headed and female-headed households. The other 61 female gardeners were members of male-headed households (but never the spouses of any of the 100 male gardeners selected). Even so, only 45 of the 100 male gardeners appeared to be married, which left no fewer than 55 who were not (i.e. single, widowed, separated or divorced). ${ }^{9}$ This makes it possible to not only compare between male gardeners and female gardeners, but also-within both groups-between married and unmarried gardeners. Hence, besides the main question regarding differences between men and women, it was possible to add a second question, namely how far the gardener's marital status played a role in the studied issues. ${ }^{10}$ As the findings show, the comparison between male and female gardeners is too simplistic and hides sometimes important differences in the underlying characteristics (in this case, the marital status) of the gardeners. It would appear that this is a new dimension in the literature on gender aspects in urban agriculture.

\section{Gender profile of the gardeners}

Table 1 presents some basic characteristics of the study groups. The unmarried female gardeners (i.e. the female household heads) were, on average, somewhat younger than the other three groups of farmers which is due to the relatively high percentage (44\%) of women aged between 20 and 30 years.

\footnotetext{
9 This surprisingly high percentage of unmarried male gardeners is an interesting finding in itself because it suggests that this group is quite overrepresented among the male gardeners (unfortunately, we do not know of any comparison study). This, in turn, indicates that these unmarried household heads have a greater need to grow crops than their married counterparts. The findings presented below suggest that this may indeed be the case.

${ }^{10}$ It is important to note that there were no cases of polygamy among the research population. Polygamy does exist in Cameroon, but not so much in the South West Region, and even less in urban areas.
} 
Table 1 Some characteristics of the gardeners, by study group

\begin{tabular}{lllll}
\hline & Male gardeners & & Female gardeners \\
\cline { 2 - 5 } & $\begin{array}{l}\text { Married } \\
(N=45)\end{array}$ & $\begin{array}{l}\text { Unmarried } \\
(N=55)\end{array}$ & $\begin{array}{l}\text { Married } \\
(N=61)\end{array}$ \\
\hline Average age of gardener $^{\mathrm{a}}$ (years) & $\mathbf{4 3}$ & $\mathbf{4 0}$ & $\mathbf{3 9}$ & $\mathbf{3 0}$ \\
Average household size & (persons) & $\mathbf{5 . 8}$ & $\mathbf{4 . 5}$ & $\mathbf{6 . 0}$ \\
Household welfare index $^{\mathrm{b}}$ (average) & 5.9 & 4.5 & 5.7 & $\mathbf{5 . 5}$ \\
\hline
\end{tabular}

Differences between the frequency distributions were tested using the Mann-Whitney U statistical test at $P=0.05$. Significant differences between male gardeners and female gardeners are indicated with bold and bolditalic. Significant differences between married and unmarried male gardeners and/or between married and unmarried female gardeners are indicated with figures in italic

a Based on class middles

b On a scale of 0 to 9 . The calculation is based on the occupational status of the household head, the head's spouse (if present) and any other household members. The highest value (3) is given to 'civil servants' (penitentiary officers, teachers, police officers etc.) followed by 'formal-sector workers' (2), 'petty business persons' in the informal sector (1) and the 'unemployed' (0). The maximum score is thus 9 ( 3 civil servants) and the minimum is 0 ( 3 unemployed). The index is not corrected for household size because household incomes in the Sub-Saharan context tend to be divided between the head and his spouse(s)

Nevertheless, the average size of these women's households was not much smaller than that of households with a married couple (i.e. the married male gardeners and the married female gardeners) because most of the female heads $(77 \%)$ were single mothers. Over half of the unmarried male gardeners were single men, which explains the smaller household sizes in this group.

The main occupations of the gardener, his/her spouse and any other household members have been used to construct a crude household welfare index (see Table 1, Note 2). ${ }^{11}$ The average welfare indexes for each study group are given in Table 1. Although there is no statistically significant difference between male and female gardeners, the difference between married and unmarried gardeners is; and not only among the female gardeners but also among the male gardeners. Especially the low welfare level of the female-headed households was conspicuous; the more so because household size was almost the same as in the other three groups. Only one female head

\footnotetext{
11 As explaine 1 in note 2 with Table 1, this 'household welfare index' is based on the main occupations of the various household members and not on household cash income (which tends to be a quite unreliable measure and therefore was not asked for) or a list of items the household possesses. In the local context, where household income depends to a large extent on whether one or more household members is a civil servant, a welfare index based on the members' main occupations, is, according to the authors, a fairly good proxy of the actual welfare level of a household (even though it is obvious that it can never be more than a crude indication).
}

was a civil servant and most had no job at all. If there were other income earners in these households, this income usually (54\%) came from low-earning petty business activities (compared with 16\% in the other three groups combined). In short, these figures indicate that female-headed households were (much) less well-off than those in the other three categories, which is in line with the findings of other studies (see e.g. Foeken 2006).

\section{The reasons for gardening}

Table 2 presents the main reasons for gardening among the 200 gardeners. A number of observations can be made. First, producing food was a more important objective for female gardeners than for male gardeners. This does not mean that the food objective was of no importance to male gardeners, particularly among the unmarried male gardeners. Second, although for only a fifth of all gardeners the income objective was the sole reason for growing crops, for a majority of the gardeners it was at least one of the reasons. In general, the income generated was more important for male gardeners than for female gardeners. However, for the female-headed households (the right-hand column in Table 2), the income objective was as important as the food objective, which can be related to the meagre sources of income in these households. For some, gardening was primarily practised to earn money, to pay for children's schooling and health needs. The income 
Table 2 Main reasons for gardening, by study group (\%)*

\begin{tabular}{|c|c|c|c|c|}
\hline & \multicolumn{2}{|c|}{ Male gardeners } & \multicolumn{2}{|c|}{ Female gardeners } \\
\hline & $\begin{array}{l}\text { Married } \\
(N=45)\end{array}$ & $\begin{array}{l}\text { Unmarried } \\
(N=55)\end{array}$ & $\begin{array}{l}\text { Married } \\
(N=61)\end{array}$ & $\begin{array}{l}\text { Unmarried } \\
(N=39)\end{array}$ \\
\hline To supplement household food supply & 51 & 69 & 89 & 79 \\
\hline To generate additional income & 62 & 62 & 33 & 74 \\
\hline Hobby/pleasure/exercise & 22 & 11 & 0 & 0 \\
\hline
\end{tabular}

Differences between the frequency distributions were tested using the Pearson Chi-Square statistical test at $P=0.05$. Significant differences between male gardeners and female gardeners are indicated with bold. Significant differences between married and unmarried male gardeners and/or between married and unmarried female gardeners are indicated with figures in bolditalic

* Totals exceed $100 \%$

aspect for female gardeners should not be underestimated. One female gardener revealed that "the amount of money I make monthly from my tomato garden, especially in the dry season, makes me feel richer than a college teacher", while another commented that "the salary I receive from the government is grossly insufficient to sustain my family; my garden is of great help".

The third observation from Table 2 is that for some people in Buea, gardening was primarily a hobby. These were only male gardeners with secure employment and a reasonable income. However, the table also shows that this was less common among the unmarried male gardeners than among the married ones, which may be related to the lower percentage of civil servants and the higher percentage of unemployed among the unmarried male gardeners. These hobby gardeners simply enjoy gardening, whereby the financial costs of production remain of no concern for them.

The main reason for gardening in town was to some extent reflected by the choice of crops (see Fig. 1). There was a general preference for highvalue crops ${ }^{12}$ because of high demand, favourable prices and easy marketing possibilities. In Buea, tomatoes and, to a lesser extent, cabbages are the most popular and frequently planted garden crops and

\footnotetext{
$\overline{12}$ High value crops are crops that are relatively cost-intensive to produce, i.e. they require more regular watering, use of pesticides and fertilisers than others. They are also more expensive in the open market. In the research area, such garden crops include tomatoes, carrots, cabbages, leeks and lettuce. Parrot et al. (2008) found an increase of the importance of cash crops and horticultural crops and a strong decline of staple crops between 1995 and 2004 in neighbouring (peri-urban) Muea.
}

are suitable as they thrive in relatively small plots. ${ }^{13}$ Other crops include lettuce, improved bitter leaf, okra, water leaf, cucumber, huckleberry, carrots, pepper and assorted spices. The market for these vegetables is not limited to Buea but includes other towns such as Limbe and Douala. Among the research population, tomatoes were the most popular crop (either or not in combination with cabbages). As Fig. 1 shows, tomatoes were more often cultivated by the male gardeners $(56 \%)$ than by the female gardeners $(24 \%)$. This difference partly reflects the relatively high input costs for these crops. Further analysis revealed that a large majority of the households cultivating tomatoes belonged to the mediumand high-welfare categories. ${ }^{14}$ Even so, very few married female gardeners whose spouse was unemployed grew tomatoes because the capital inputs required are usually provided by the male spouse.

In terms of crop choice, unmarried female farmers were again a special group (Fig. 1). Compared with the other three groups, they were much more inclined to cultivate basic food crops (64 vs. $25 \%$ of the combined male gardeners and married female gardeners) such as maize, beans, potatoes and okra. Feeding the household would appear to be their prime concern but the income objective had to be realised from these same, relatively low-rewarding crops. A large majority of the female heads were unemployed and none of those cultivated tomatoes. Of the eight female heads that did have an external income, half

\footnotetext{
${ }^{13}$ In terms of Webb's (1998) 'index of crop importance', tomatoes would score high in the context of Buea.

${ }^{14}$ Referring to Table 1 , Note 2, 'medium' is a score of 4 to 6 and 'high' of 7 to 9 .
} 


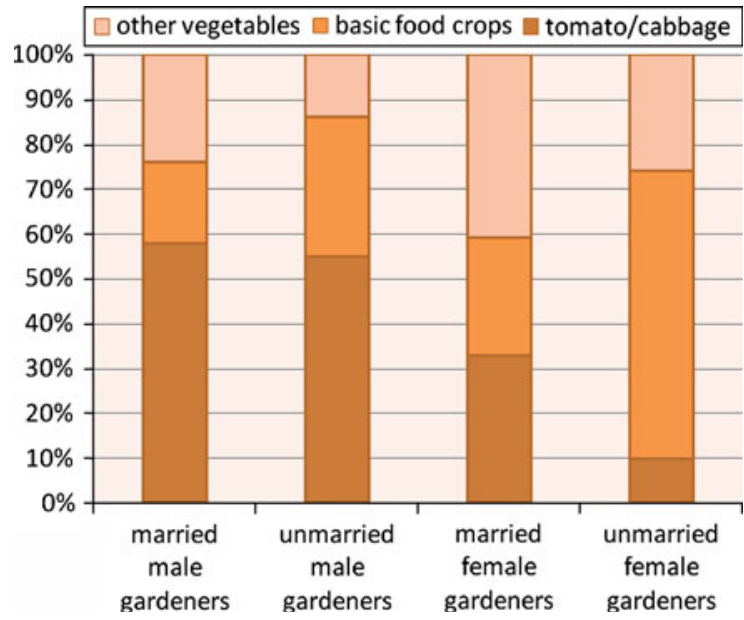

Fig. 1 Types of crops cultivated, by study group (\%). Differences between the frequency distributions were tested using the Pearson Chi-Square statistical test at $P=0.05$. The differences between men and women, and between married and unmarried female gardeners are significant

grew tomatoes, including the one civil servant in the group. The major obstacles for these poor households are a lack of capital and time, as the cultivation of high-value crops is both financially and time intensive.

Access to land and improved seeds

A substantial percentage (about $45 \%$ ) of gardens in the Buea agglomeration are located on governmentowned land, usually around government-rented houses and public offices and in open spaces belonging to the government (BRC, n.d.). This is even more the case in the three Farms neighbourhoods where over $90 \%$ of urban open space belongs to the government. Access to this land does not seem to be based on gender differences. For instance, people in Buea can obtain a plot to garden on by applying to the municipality. From the municipal files covering the 5 years between 2002 and 2006, it was possible to establish that more women $(59 \%)$ than men $(41 \%)$ obtained a plot in this way (Ibid.). From discussions with respondents, it emerged that the leasing of urban open spaces by Buea Council is organised on the basis of three criterions: (a) firstcome-first-served; (b) the applicant's ability to pay the rent; and (c) the preparedness to respect the Council's conditions regarding the types of crops that can be cultivated and the methods of cultivation. ${ }^{15}$ Men and women have equal opportunities concerning urban open spaces.

Equality of access for both sexes was confirmed by the research findings. For instance, the large majority of the gardeners-male and female alike-agreed that anyone can rent land from the Municipal Council and almost all of them actually farmed on government-owned land, i.e. either in their compound of a government-rented house or in a government-owned open space. About $65 \%$ of male gardeners and $40 \%$ of married female gardeners had rented a plot on an open space. However, this figure was much higher among unmarried female gardeners $(82 \%)$ because few of them lived in government houses with compounds. Moreover, none of the unmarried female gardeners owned any land, while some gardeners in the other three groups did. Interestingly, $25 \%$ of the male gardeners - but none of the female gardenersrefused to answer the question about how they had acquired their plots. ${ }^{16}$

Although access to land as such does not show gender differences, it is different when looking at plot sizes (Table 3). The overall average plot size per household was about $380 \mathrm{~m}^{2}$, which is larger than Page (2002) found in 1998. In general, male gardeners cultivated bigger plots than female gardeners. This is particularly due to the high percentages of female gardeners with small plots (i.e. less than $300 \mathrm{~m}^{2}$ ). The fact that unmarried male gardeners as well as unmarried female gardeners had somewhat bigger plots than their married counterparts (though not statistically significant among the female gardeners) may be related to the higher 'level of survival' by means of gardening for the former groups, which is in line with the fact that more married gardeners-or their spouses-were employed than unmarried ones.

Improved seeds can better withstand climatic and biological influences and result in larger harvests. A substantial proportion of the male (80\%) and female

\footnotetext{
15 As for the Council's conditions, it is for instance not permitted to plant perennial crops on public spaces. Also, those cultivating near streets are not allowed to plant crops that grow taller than one metre (such as maize), as such crops may constitute hiding places for thugs, particularly at night. Slashand-burn farming is also not permitted near streets and public offices.

16 This might be interpreted as a sign of corruption in favour of men.
} 
Table 3 Size of garden $\left(\mathrm{m}^{2} /\right.$ household), by study group (\%)

\begin{tabular}{|c|c|c|c|c|}
\hline & \multicolumn{2}{|c|}{ Male gardeners } & \multicolumn{2}{|c|}{ Female gardeners } \\
\hline & $\begin{array}{l}\text { Married } \\
(N=45)\end{array}$ & $\begin{array}{l}\text { Unmarried } \\
(N=55)\end{array}$ & $\begin{array}{l}\text { Married } \\
(N=61)\end{array}$ & $\begin{array}{l}\text { Unmarried } \\
(N=39)\end{array}$ \\
\hline$<300$ & 36 & 20 & 64 & 51 \\
\hline 300-799 & 60 & 76 & 25 & 44 \\
\hline $800+$ & 4 & 4 & 11 & 5 \\
\hline Total & 100 & 100 & 100 & 100 \\
\hline Estimated average plot size $*\left(\mathrm{~m}^{2}\right)$ & 394 & 470 & 308 & 342 \\
\hline
\end{tabular}

Differences between the frequency distributions were tested using the Mann-Whitney $\mathrm{U}$ statistical test at $P=0.05$. Significant differences between male gardeners and female gardeners are indicated with bold and bolditalic. Significant differences between married and unmarried male gardeners and/or between married and unmarried female gardeners are indicated with figures in italic

* Based on class middles

(62\%) gardeners in Buea did buy improved seeds, with the majority purchasing them in neat packages from local shops. Ten gardeners (nine men and one woman) went to the nearest agricultural research post—either the South West Development Authority (SOWEDA) in Buea or the Agricultural Research and Development Institute (IRAD) in Ekona-to purchase improved seeds for their gardens. The above figures suggest that more male than female gardeners could afford the costs of improved seeds. This links with the finding that more men than women have access to sources of income other than gardening; hence, more men than women can afford to grow high value crops and purchase improved seeds. The percentage of unmarried female gardeners who did not (or were not able to) purchase improved seeds was much higher (44\%) than among the other three groups (14\%), which is once again an indication of their difficult financial situation.

Some $20 \%$ of all gardeners did not buy seeds. Some depended on relatives or friends for seeds but most of them $(15 \%)$ were confident that they can select seeds from one harvest and successfully store and prepare them for another planting season.

\section{Division of labour}

Appendix gives an overview of the division of labour between the sexes for various activities related to urban gardening in Buea. The first (general) observation from these figures is that for each of the activities, the work was to some extent divided between the men and the women in the household, with the notable exception of unmarried female gardeners' households. Even preparing land, which is typically a 'man's domain' in Sub-Sahara Africa's agriculture (and in the area under study this involves the tedious task of digging out elephant grass), was carried out by a woman in the household in about $25 \%$ of the male-headed households (which includes the households of the married female gardeners). This was also the only task that (male) hired labour was used for, albeit in only ten households $(5 \%){ }^{17}$

The second general observation that emerges from Appendix is that the females in the male-headed households were more involved in various gardening tasks than men, irrespective of whether the gardener was a man or a woman. ${ }^{18}$ In addition to land preparation, there appeared to be two exceptions to this rule. The first involved the weeding of plots of the unmarried male gardeners and the second was the

\footnotetext{
17 This is in sharp contrast with the findings of Ngwa (1987) in the mid-1980s when most labour was carried out by hired labourers, but also with Parrot et al. (2008) who noticed a strong increase of hired labour between 1995 and 2004 among horticulturalists in peri-urban (neighbouring) Muea. At the end of the 1990s, Page (2002) found that wives and youth did most of the work, although Bakweri women were sometimes employed to do the initial land clearance. The present study did not see any evidence of an ethnic division of labour and confirms that labour was predominantly recruited from within the household; in other words, most households can no longer afford the extra costs of hiring labour.

18 This becomes clear when for each task presented in Appendix , the category 'both males and females' is added to 'males in the household' and 'females in the household', respectively.
} 
application of chemicals to the plots of the married male gardeners. For both exceptions, there does not appear to be a ready explanation.

Despite the observations in the previous paragraph, a third conclusion to be drawn from Appendix is that married male gardeners were more involved in agricultural tasks on their own plots than the husbands of the married female gardeners were on the latter's plots. Apparently, many married male gardeners did not hesitate to perform such 'female tasks' as sowing, weeding and watering when it concerned their own crops. Land preparation was again the (expected) exception. Interestingly, when it came to harvesting and selling of the married female gardeners' crop, the men in these households were also involved. This is an indication that when it comes to actually benefitting from the activities of the female spouse's garden, the male spouse appears on stage. ${ }^{19}$

One would expect more male involvement on the plots of the unmarried male gardeners than on the plots of the married male gardeners, as there is no female spouse in the former households. Surprisingly, that was only clearly the case with sowing/planting which suggests that despite the 'lack' of a female spouse, other females (like daughters) in the households of the unmarried male gardeners performed (a lot of) labour in the household head's garden. Sometimes this may be even more than the females in the households of the married male gardeners (like for instance with applying chemicals, harvesting and selling the harvest). Conspicuously, the unmarried male gardeners appeared to be only marginally involved in selling the harvest. This may be because unmarried men hesitate to sit with women in markets retailing vegetables and they find it easier to ask a female relative to take on this task and sell their produce on their behalf.

Finally, some exceptions to the trends described above can be found among the unmarried female gardeners. Although in some of these female-headed households, there are one or more female members old enough and strong enough to work in the garden, the figures in Appendix show that female gardeners did almost all the work themselves, including land preparation, weeding and applying chemicals. The

\footnotetext{
${ }^{19}$ See the 54 and $72 \%$ 'both males and females' for 'harvesting' and 'selling the harvest', respectively, in the 'married female gardeners' column in Appendix .
}

importance of these latter two tasks should not be underestimated because the high amount of rainfall and high average temperatures in the research area may be good for crops but also present ideal conditions for weeds, fungi, insects and other pests to proliferate.

Since most of the respondents were employed, work in the garden could not usually be done during daytime hours on working days. In general, the working patterns of male and female gardeners did not differ very much in this respect. About a third of the respondents indicated that work in their garden was done early in the morning before household heads left home to engage in other duties. Such early morning gardening activities included watering the nurseries or vegetable beds or harvesting fruit and vegetables. Women and female children were the ones who mostly did the watering and harvesting of crops, getting up early to carry out their routine household chores such as food preparation, fetching water, child care and cleaning, and tending their gardens.

About half of the gardeners worked in their gardens in the evening. However, this was more common among male gardeners than among female gardeners, apparently because the men have limited domestic responsibilities (see e.g. Levine et al. 2001). This was confirmed by the way gardeners spent their free time. Over $80 \%$ of female gardeners spent their evenings performing tasks such as cooking, sewing or helping their children with their homework. Conversely, 75\% of the male gardeners reported that they spent time in the evenings with friends in beer parlours, at traditional meetings or at home watching TV.

\section{Benefits and challenges}

As indicated in Table 2, the most important benefit for the large majority of gardeners was the increase in their food security, a finding reported in other studies as well (see e.g. Freeman 1993; Foeken 2006). This was confirmed by answers about their household's most important food source. Almost $66 \%$ of the gardeners considered their own food production as the most important source of calories and protein. However, there was a substantial difference between male and female gardeners in this respect, namely 35 and $92 \%$, respectively. Although this may partly be a matter of different perceptions by men and women, it 
may also be explained by the fact that male gardeners are more involved in commercial crop cultivation than female farmers. Female-headed households in particular relied heavily on their urban gardens for their household's food security, as all except one regarded their garden as their most important source of food.

Gardeners do not only grow crops for quantity but also to improve the household's dietary composition. Usually it is easier and cheaper for residents in the study area to purchase calorie-rich foodstuffs like cassava, plantains, cocoyam and potatoes than to buy vitamin and protein sources like vegetables. For most of the respondents, therefore, having gardens near their home is indispensable in providing the household with an adequately balanced diet.

Buea town gardeners faced manifold problems (Table 4). Respondents were asked to indicate the major problems they face. The most frequently mentioned problem concerned the high prices of agricultural chemicals such as fertilizers, pesticides and fungicides. This is an important issue in Buea because the hot humid climate causes substantial preharvest and post-harvest losses due to birds, rodents, fungi and a host of microbes. Popular opinion in town is that tomatoes, leeks, cabbages and carrots are especially vulnerable in this respect. Table 4 shows that this was particularly a problem for female farmers. These women said that the high price of chemicals constituted the greatest barrier to the cultivation of crops with a high market value, and at the same time contributed to restricting the size of the garden they wanted to cultivate. Those female gardeners who were married and depended on their spouses for capital said that the high cost of chemicals was onerous as they always needed to develop strategies to obtain money from their spouses for this purpose. Those unmarried male gardeners and unmarried female gardeners who had no or little other income said they always had difficulties to get money from friends, relatives and microcredit organisations to cover gardening costs. However, the fact that more women than men cited this as their principal problem confirms the earlier finding that most male gardeners in this part of Buea were employed in other economic sectors and were thus more likely to be able to afford the cost of chemicals than women.

Lack of farm equipment to assist cultivation appeared to be a typical male gardeners' complaint, although quite a number of the unmarried female gardeners mentioned this as well (see Table 4). The background to this is the recent hike in taxes in Cameroon-particularly in Value Added Tax (VAT) — on the prices of basic commodities. This tax reform was one of the measures endorsed by the government in order to be eligible for the Highly Indebted Poor Countries Initiative. Costs of farm implements such as cutlasses and hoes have increased. This is especially felt by the men because, culturally, it is the man who buys tools for his household, regardless of whether he himself practises farming or not, and by those female heads who do not have a man in the household to buy this equipment on their behalf.

Lack of education and training is a crucial limitation to the success of gardening in Buea and

Table 4 Problems with urban gardening, by study group (\%)*

\begin{tabular}{|c|c|c|c|c|}
\hline & \multicolumn{2}{|c|}{ Male gardeners } & \multicolumn{2}{|c|}{ Female gardeners } \\
\hline & $\begin{array}{l}\text { Married } \\
(N=45)\end{array}$ & $\begin{array}{l}\text { Unmarried } \\
(N=55)\end{array}$ & $\begin{array}{l}\text { Married } \\
(N=61)\end{array}$ & $\begin{array}{l}\text { Unmarried } \\
(N=39)\end{array}$ \\
\hline Expensive farm chemicals & 24 & 29 & 97 & 100 \\
\hline Lack of farm equipment & 82 & 71 & 0 & 33 \\
\hline Lack of education/training & 18 & 24 & 59 & 64 \\
\hline Theft & 27 & 40 & 18 & 5 \\
\hline Lack of land & 38 & 20 & 20 & 8 \\
\hline Market constraints & 2 & 9 & 15 & 0 \\
\hline
\end{tabular}

Differences between the frequency distributions were tested using the Pearson Chi-Square statistical test at $P=0.05$. Significant differences between male gardeners and female gardeners are indicated with bold and bolditalic. Significant differences between married and unmarried male gardeners and/or between married and unmarried female gardeners are indicated with figures in italic

* Totals exceed $100 \%$ 
it was the third highest constraint in urban gardening (Table 4). This applies to female gardeners in particular, most of whom indicated that they did not actually know which pesticides needed to be applied on which crop, in what quantities and how frequently. The entire application activity seemed to be based on a trial-and-error basis and some respondents reported that certain small non-governmental organisations (NGOs) had organised workshops to educate urban farmers in Buea in the use of agricultural chemicals and marketing strategies. Unfortunately the NGOs were reported to have invited only heads of households, which technically disqualified some women from participating in the training sessions even though they were the main gardeners in their households. As one of the female gardeners said, " $[\mathrm{M}] \mathrm{y}$ husband does not work in my garden, but he was invited for training. I, who works in the garden, was not invited simply because I'm not the head of any family." This opinion was echoed by a number of other women who were equally keen to participate in training but had not been invited to do so.

Quite a number of gardeners mentioned theft as a serious setback to their activities. This appeared to be more of a problem for male gardeners than for female gardeners (Table 4) and could be related to the relatively high market value of their crops, as more men than women cultivated high-value crops that attract thieves. Table 4 also shows that among the male gardeners, the unmarried ones complained more often about theft (although the difference is not statistically significant). This may be due to the fact that quite a number of the latter (20\%) had a relatively unprotected garden, for example somewhere near a major road, while the large majority of the other three gardeners' groups $(93 \%)$ had relatively protected gardens near their houses or near a public office. Respondents indicated that theft was on the increase. A possible explanation could be the deteriorating economic situation of the ordinary Cameroonian over the years, resulting in high levels of unemployment and poverty. The continuous increase in food prices, especially in Buea, has only exacerbated the desperation of those lacking access to food.

Lack of land was also mentioned by quite a number of gardeners, especially men, and the married male gardeners in particular (38\%) (see Table 4). High rates of urbanisation are not only driving up food prices but also forcing people to compete for land. With an economy that does not seem to be improving, male household heads are under pressure to meet their families' needs, even through agriculture. The lack of available farmland is affecting them more than others.

Factors like these undermine the urban gardening sector and the involvement of poor persons of both sexes in urban gardening for income generation. So rather than fostering food self-sufficiency, prices of garden crops are actually increasing, making nutritious vegetables less accessible to many poor people. Such limitations are accentuating the food crisis, particularly in a town like Buea with its high urbanisation rate. When asked how such problems could be solved, respondents came up with the obvious suggestions: prices of farm chemicals and equipment should be reduced, farmers should be educated in the use of chemicals, and more undeveloped urban land should be made available to interested gardeners. However, specific solutions were also mentioned. For instance, $79 \%$ of the male gardeners and $31 \%$ of the female gardeners suggested the provision of cooled, public storage facilities so that the severe post-harvest losses could be reduced. A step further was the suggestion that the government should build a tomato factory so that there would always be a ready market for tomato farmers. Another example mentioned by some gardeners concerned the organisation of agricultural shows to encourage farmers and offer them further opportunities for education.

\section{Conclusions}

According to Kevane (2004: 1), "a common outcome of the gendering of social activity is an unequal and inefficient distribution, between men and women, of the capabilities for realizing well-being." Urban crop cultivation is one such social activity, from which "men reap more benefits than women", as Hovorka et al. (2009: 14) argue. Indeed, as for most of the gender issues in urban agriculture outlined above, the findings of the Buea study were more or less in line with the general picture outlined by Hovorka et al. (2009). ${ }^{20}$ For instance, compared to male gardeners,

\footnotetext{
${ }^{20}$ Moreover, nearly all differences between male gardeners and female gardeners appeared to be statistically significant.
} 
female gardeners had smaller plots and regarded gardening chiefly as a supplementary source of food for their households, while men tended to see it first and foremost as a supplementary source of income. This was also visible in the types of crops the female gardeners cultivated (fewer commercial crops and more food crops) and the very high percentage claiming that their urban garden was their household's most important source of food. As for the division of labour, although all the tasks to be done were also carried out by men, the women did most of the work, irrespective of whose plot it was. Male and female gardeners also differed in terms of the problems they perceived regarding urban farming. While female gardeners complained about the high costs of chemical inputs and the lack of education and training, their male counterparts worried more about expensive farm equipment and to a lesser extent also theft and lack of land. Only in terms of access to land, no difference between men and women was found.

However, this general gender division conceals substantial differences between married and unmarried female gardeners. The latter (female-headed households) are often portrayed as equal to poverty, or even the 'poorest of the poor'. Although Chant (2007) calls this the 'myth of the female-headed household', the present study does confirm that the unmarried female gardeners were worse off than their married colleagues. They appeared to be significantly poorer, so the income aspect of their gardening activities was as important as the food one, even though they were barely involved in commercial cropping. The additional income generated had to come mainly from selling their small surpluses of food crops. In terms of labour, they had practically no help from any male household member, not even with preparing the land. Many of them complained of a lack of farm equipment, while none of the married female gardeners did. These differences illustrate the female-headed households' difficult situation, the more so because very few had a civil servant (and thus a regular income) in the household. As a result, they had to a large extent to rely on their urban garden for the household's food supply but were hardly in a position to invest in it.

To a lesser extent, there also appeared to be differences between the married and unmarried male gardeners. The results suggest that the latter were quite overrepresented, which may be related to their (statistically significant) lower welfare level, due to the fact that there were comparatively fewer civil servants and more unemployed people among them. Probably for that reason, they cultivated larger plots and were more focused on their household's food supply in comparison with the married male gardeners.

Like other studies on urban farming, the Buea study shows that farming in town is an important livelihood activity for both men and women. There is no sign that the number of people involved in agriculture will significantly decline in the near future (World Bank 2007) and many of these farmers will live in urban areas. In Cameroon for instance, between 10 and 30\% of all farmers are expected to live in towns by 2030 (Parrot et al. 2008: 254). The rise in informal urban horticulture will require new efforts from local governments and support institutions to guide and monitor this process. The reduction of land availability coupled with the increasing number of urban farmers requires the intensification of agriculture and adequate land policies (Ibid.: 255). Appropriate policies in the field of urban agriculture are needed to encourage gardeners to change from growing food on an ad hoc basis to being reliable partners in the food production process, and thus transforming urban areas from essentially food-consuming to food-producing places. Some of these policies will and can be 'gender-neutral' (i.e. as having no discernable differentiated impact on either male or female). Examples in the Buea context are (1) a reduction of the price for farm implements and (chemical) inputs, so that these become more affordable to low-income gardeners; (2) the provision of means to conserve harvests to prevent post-harvest losses; (3) increased accessibility to microcredit to both the men and women who hope to venture into gardening; and (4) the possibility of renting private open spaces from owners and in turn leasing them to gardeners.

However, 'gender-neutral' policy measures are not enough, because, according to Cornwall (2004: 29), “'gender-neutral' policies are often simply 'genderblind' (i.e. lacking 'awareness of distinctions of gender', or refusing 'to acknowledge gender')". Education by means of training programmes on new farming techniques - such as the application of farm chemicals - focusing on female gardeners is one possible 'gender-sensitive' policy measure; the more so as the female gardeners in Buea themselves expressed a need for it. Another gender-sensitive 
policy could be the stimulation of community-based organisations focusing on urban gardening. Many such groups exist in Sub-Saharan Africa, especially among women. If well organised, they can be quite successful, as was shown for instance in Cotonou (Brock and Foeken 2006) or in Peddie, South Africa (Thornton 2009). Yet, pro-female government policies are still very rare in Africa because it requires a fundamental change in people's thinking. In other words, to quote Kevane's (2004: 191) conclusion, "much work remains to be done".
Acknowledgments We owe special thanks to Wijnand Klaver for his assistance with the statistical analysis.

Open Access This article is distributed under the terms of the Creative Commons Attribution Noncommercial License which permits any noncommercial use, distribution, and reproduction in any medium, provided the original author(s) and source are credited.

\section{Appendix}

See Table 5.

Table 5 Division of labour, by study group (\%)

\begin{tabular}{|c|c|c|c|c|}
\hline & \multicolumn{2}{|c|}{ Male gardeners } & \multicolumn{2}{|c|}{ Female gardeners } \\
\hline & $\begin{array}{l}\text { Married } \\
(N=45)\end{array}$ & $\begin{array}{l}\text { Unmarried } \\
(N=55)\end{array}$ & $\begin{array}{l}\text { Married } \\
(N=61)\end{array}$ & $\begin{array}{l}\text { Unmarried } \\
(N=39)\end{array}$ \\
\hline \multicolumn{5}{|l|}{ Land preparation } \\
\hline Males in household & 69 & 73 & 66 & 3 \\
\hline Females in household & 22 & 26 & 16 & 92 \\
\hline Both males and females & 2 & 2 & 7 & 5 \\
\hline Hired labour & 7 & $\mathbf{0}$ & 12 & 0 \\
\hline Total & 100 & 100 & 100 & 100 \\
\hline \multicolumn{5}{|l|}{ Sowing/planting } \\
\hline Males in household & 20 & 26 & 2 & $\mathbf{0}$ \\
\hline Females in household & 62 & 44 & 93 & 100 \\
\hline Both males and females & 18 & 31 & 5 & $\mathbf{0}$ \\
\hline Total & 100 & 100 & 100 & 100 \\
\hline \multicolumn{5}{|l|}{ Weeding } \\
\hline Males in household & 18 & 38 & 2 & $\mathbf{0}$ \\
\hline Females in household & 36 & 24 & 77 & 87 \\
\hline Both males and females & 47 & 38 & 21 & 13 \\
\hline Total & 100 & 100 & 100 & 100 \\
\hline \multicolumn{5}{|l|}{ Watering } \\
\hline Males in household & 9 & 9 & 28 & $\boldsymbol{0}$ \\
\hline Females in household & 33 & 47 & 51 & 54 \\
\hline Both males and females & 58 & 44 & 21 & 46 \\
\hline Total & 100 & 100 & 100 & 100 \\
\hline \multicolumn{5}{|l|}{ Applying chemicals } \\
\hline Males in household & 62 & 42 & 28 & 0 \\
\hline Females in household & 36 & 56 & 62 & 100 \\
\hline Both males and females & 2 & 2 & 10 & 0 \\
\hline Total & 100 & 100 & 100 & 100 \\
\hline \multicolumn{5}{|l|}{ Harvesting } \\
\hline Males in household & 36 & 15 & 13 & 0 \\
\hline Females in household & 38 & 56 & 33 & 80 \\
\hline Both males and females & 27 & 29 & 54 & 21 \\
\hline Total & 100 & 100 & 100 & 100 \\
\hline
\end{tabular}


Table 5 continued

\begin{tabular}{|c|c|c|c|c|}
\hline & \multicolumn{2}{|c|}{ Male gardeners } & \multicolumn{2}{|c|}{ Female gardeners } \\
\hline & $\begin{array}{l}\text { Married } \\
(N=45)\end{array}$ & $\begin{array}{l}\text { Unmarried } \\
(N=55)\end{array}$ & $\begin{array}{l}\text { Married } \\
(N=61)\end{array}$ & $\begin{array}{l}\text { Unmarried } \\
(N=39)\end{array}$ \\
\hline \multicolumn{5}{|l|}{ Selling the harvest } \\
\hline Males in household & 36 & 20 & 7 & 0 \\
\hline Females in household & 38 & 69 & 21 & 97 \\
\hline Both males and females & 27 & 11 & 72 & 3 \\
\hline Total & 100 & 100 & 100 & 100 \\
\hline
\end{tabular}

Differences between the frequency distributions were tested using the Pearson Chi-Square statistical test at $P=0.05$. Significant differences between male gardeners and female gardeners are indicated with bold. Significant differences between married and unmarried male gardeners and/or between married and unmarried female gardeners are indicated with figures in bolditalic

\section{References}

Anosike, V., \& Fasona, M. (2004). Gender dimensions of urban commercial farming in Lagos, Nigeria. Urban Agriculture Magazine, 12, 27-28.

Bah, M., Cissé, S., Diyamett, B., Diallo, G., Lerise, F., Okali, D., et al. (2003). Changing rural-urban linkages in Mali, Niger and Tanzania. Environment and Urbanization, 15(1), 13-23.

Beall, J. (2002). Living in the present, investing in the futureHousehold security among the urban poor. In C. Rakodi \& T. Lloyd-Jones (Eds.), Urban livelihoods: A people-centred approach to reducing poverty (pp. 71-87). London: Earthscan.

Beauchemin, C., \& Bocquier, P. (2003). Migration and urbanization in francophone West Africa: A review of the recent empirical evidence. Paris: DIAL, Document de Travail, DT/2003/09.

Bebbington, A. (1999). Capitals and capabilities: A framework for analyzing peasant viability, rural livelihoods and poverty. World Development, 17(12), 2021-2044.

BRC (not dated). Buea Rural Council, Municipal Land Lease, Registration Ledger 664. Buea: Buea Rural Council.

Brock, B., \& Foeken, D. (2006). Urban horticulture for a better environment: A case study of Cotonou, Benin. Habitat International, 30, 558-578.

Brown, A., \& Lloyd-Jones, T. (2002). Spatial planning, access and infrastructure. In C. Rakodi \& T. Lloyd-Jones (Eds.), Urban livelihoods: A people-centred approach to reducing poverty (pp. 188-204). London: Earthscan.

Chambers, R. (1983). Rural development: Putting the last first. Harlow: Longman.

Chancellor, F. (2004). Gender, water and urban agriculture. Urban Agriculture Magazine, 12, 18-19.

Chant, S. (2007). Dangerous equations? How female-headed households became the poorest of the poor: Causes, consequences and cautions. In A. Cornwall, E. Harrison, \& A. Whitehead (Eds.), Feminisms and development: Contradictions, contestations and challenges (pp. 35-47). London: Zed Press.

Cornwall, L. (2004). Mainstreaming gender: Imperatives for development studies. Africanus, 34(1), 51-63.

Danso, G., Cofie, O., Annang, L., Obuobie, E., \& Keraita, B. (2004). Gender and urban agriculture. Accra:
International Water Management Institute, West Africa sub-regional Office.

De Haan, L., \& Zoomers, A. (2003). Development geography at the crossroads of livelihood and globalization. Tijdschrift voor Economische en Sociale Geografie, 94(3), 350-362.

Ellis, F. (2000). Rural livelihoods and diversity in developing countries. Oxford: Oxford University Press.

Foeken, D. (2006). To subsidise my income. Urban farming in an East-African town. Leiden: Brill.

Foeken, D., \& Owuor, S. O. (2008). Farming as a livelihood source for the urban poor in Nakuru, Kenya. Geoforum, 39(6), 1978-1990.

Foeken, D., Sofer, M., \& Mlozi, M. (2004). Urban agriculture in Tanzania: Issues of sustainability. Leiden: African Studies Centre. Research Report 75.

Folifac, F., Lifongo, L., Nkeng, G., \& Gaskin, S. (2009). Municipal drinking water source protection in low income countries: Case of Buea municipality-Cameroon. Journal of Ecology and Natural Environment, 1(4), 73-84.

Freeman, D. B. (1993). Survival strategy or business training ground? The significance of urban agriculture for the advancement of women in African cities. African Studies Review, 36(3), 1-22.

Gbadegesin, A. (1991). Farming in the urban environment of a developing nation: A case study from Ibadan in Nigeria. The Environmentalist, 11(2), 102-111.

Gockowski, J., Mbazo'o, J., Mbah, G., \& Moulende, T. F. (2003). African traditional leafy vegetables and the urban and peri-urban poor. Food Policy, 28(3), 221-235.

Hansen, K. T., \& Vaa, M. (2004). Reconsidering informality. Perspectives from urban Africa. Uppsala: Nordiska Afrikainstitutet.

Hope, L., Cofie, O., Keraita, B., \& Drechsel, P. (2009). Gender and urban agriculture: The case of Accra, Ghana. In A. Hovorka, H. de Zeeuw, \& M. Njenga (Eds.), Women feeding cities. Mainstreaming gender in urban agriculture and food security (pp. 65-78). Bourton on Dunsmore (UK): Practical Action Publishing.

Hovorka, A. (2001). Gender and urban agriculture: Emerging trends and areas for future research. Worcester, MA: Clark University, Graduate School of Geography.

Hovorka, A., De Zeeuw, H., \& Njenga, M. (Eds.). (2009). Women feeding cities. Mainstreaming gender in urban 
agriculture and food security. Bourton on Dunsmore (UK): Practical Action Publishing.

Ishani, Z. (2009). Key gender issues in urban livestock keeping and food security in Kisumu, Kenya. In A. Hovorka, H. de Zeeuw, \& M. Njenga (Eds.), Women feeding cities. Mainstreaming gender in urban agriculture and food security (pp. 105-122). Bourton on Dunsmore (UK): Practical Action Publishing.

Jones, S. (1999). Defining urban poverty: An overview. In S. Jones \& N. Nelson (Eds.), Urban poverty in Africa. From understanding to alleviation (pp. 9-15). London: Intermediate Technology Publications.

Kaag, M., Van Berkel, R., Brons, J., De Bruijn, M., Van Dijk, H., De Haan, L., et al. (2004). Ways forward in livelihood research. In D. Kalb, W. Pansters, \& H. Siebers (Eds.), Globalization and development: Themes and concepts in current research (pp. 49-74). Dordrecht: Kluwer.

Kanji, N. (1995). Gender, poverty and structural adjustment in Harare, Zimbabwe. Environment and Urbanization, 7(1), $37-55$.

Kessler, A., Streiffeler, F., \& Obuobie, E. (2004). Women in urban agriculture in West Africa. Urban Agriculture Magazine, 12, 16-17.

Kevane, M. (2004). Women and development in Africa: How gender works. Boulder, CO: Lynne Riener.

Kiguli, J., \& Kiguli, L. N. (2004). Gender and access to land for urban agriculture in Kampala, Uganda. Urban Agriculture Magazine, 12, 34-35.

Levine, J. A., Weisell, R., Chevassus, S., Martinez, C. D., Burlingame, B., \& Coward, W. A. (2001). The work burden of women. Science, 294(5543), 812.

Momsen, J. H. (2004). Gender and development. London: Routledge.

Nabulo, G., Nasinyama, G., Lee-Smith, D., \& Cole, D. (2004). Gender analysis of urban agriculture in Kampala, Uganda. Urban Agriculture Magazine, 12, 32-33.

Ngwa, N. (1987). Time and land space utilization within an urban confine: The case of Buea Town gardeners in the Republic of Cameroon. Geoforum, 15(1), 77-81.

Njenga, M., Karanja, N., Gathuru, K., Mbugua, S., Fedha, N., \& Ngoda, B. (2009). The role of women-led microfarming activities in combating HIV/AIDS in Nakuru, Kenya. In A. Hovorka, H. de Zeeuw, \& M. Njenga (Eds.), Women feeding cities. Mainstreaming gender in urban agriculture and food security (pp. 167-180). Bourton on Dunsmore (UK): Practical Action Publishing.

Owuor, S. O., \& Foeken, D. (2006). Surviving in the neighbourhoods of Nakuru town, Kenya. In P. Konings \& D. Foeken (Eds.), Crisis and creativity. Exploring the wealth of the African neighbourhood (pp. 22-45). Leiden: Brill.
Page, B. (2002). Urban agriculture in Cameroon: An antipolitics machine in the making? Geoforum, 33(1), 41-54.

Parrot, L., Dongmo, C., Ndoumbé, M., \& Poubom, C. (2008). Horticulture, livelihoods, and urban transition in Africa: Evidence from South-West Cameroon. Agricultural Economics, 39(2), 245-256.

Rakodi, C. (2002a). A livelihoods approach-conceptual issues and definitions. In C. Rakodi \& T. Lloyd-Jones (Eds.), Urban livelihoods: A people-centred approach to reducing poverty (pp. 3-22). London: Earthscan.

Rakodi, C. (2002b). Economic development, urbanization and poverty. In C. Rakodi \& T. Lloyd-Jones (Eds.), Urban livelihoods: A people-centred approach to reducing poverty (pp. 23-34). London: Earthscan.

Tacoli, C. (2002). Changing rural-urban interactions in SubSaharan Africa and their impact on livelihoods: A summary. London: International Institute for Environment and Development (IIED), working paper 7 on rural-urban interactions and livelihood strategies.

Thornton, A. (2008). Beyond the metropolis: Small town case studies of urban and peri-urban agriculture in South Africa. Urban Forum, 19(3), 243-262.

Thornton, A. (2009). Pastures of plenty?: Land rights and community-based agriculture in Peddie, a former homeland town in South Africa. Applied Geography, 29(1), $12-20$.

Toriro, P. (2009). Gender dynamics in the Musikavanhu urban agriculture movement, Harare, Zimbabwe. In A. Hovorka, H. de Zeeuw, \& M. Njenga (Eds.), Women feeding cities. Mainstreaming gender in urban agriculture and food security (pp. 93-104). Bourton on Dunsmore (UK): Practical Action Publishing.

Wallman, S. (1996). Kampala women getting by: Well-being in the time of AIDS. London: James Currey.

Webb, N. (1998). Urban cultivation: Food crops and their importance. Development Southern Africa, 15(2), 201-213.

Whitehead, A. (2002). Tracking livelihood change: Theoretical, methodological and empirical perspectives from north-east Ghana. Journal of Southern African Studies, 28(3), 575-598.

Wilbers, J., Hovorka, A. \& Van Veenhuizen, R. (Eds.) (2004a). Gender and urban agriculture. Special issue of Urban Agriculture Magazine, 12.

Wilbers, J., Hovorka, A., \& Van Veenhuizen, R. (2004b). Editorial. Urban Agriculture Magazine, 12, 1-3.

World Bank. (2007). Global economic prospects 2007: Managing the next wave of globalisation. Washington, DC: World Bank. 